\title{
Bridging Gaps: From a Descriptive to a Practical Mid-Space Actor Typology?
}

\author{
Anna Deekeling and Dablia Simangan
}

\section{INTRODUCTION}

Critiques of top-down approaches to peacebuilding propose that midspace actors are more effective agents in fostering connections and dialogue between bottom/local or grassroots and presumably disengaged top/national and international actors. A recent work that advocates such a proposition is a volume edited by Yuji Uesugi entitled Hybrid Peacebuilding in Asia, which aims to "fill the gap...between local stakeholders and outside intervenors" and elevate the notion of hybridity in peacebuilding from an analytical lens to a useful tool for post-conflict reconciliation processes (Uesugi and Kagawa 2020: 42). The book employs an actor-based typology to conceptualise "mid-space

\footnotetext{
A. Deekeling $(\bowtie)$

Graduate School of Social Science, Waseda University, Tokyo, Japan e-mail: annadeekeling@fuji.waseda.jp

D. Simangan

Graduate School of Humanities and Social Sciences, Hiroshima University, Hiroshima, Japan

e-mail: simangan@hiroshimau.ac.jp

(C) The Author(s) 2021

Y. Uesugi et al. (eds.), Operationalisation of Hybrid Peacebuilding in Asia, Security, Development and Human Rights in East Asia, https://doi.org/10.1007/978-3-030-67758-9_4
} 
local bridge-builders" that might become active advocates for dialoguebuilding and peace negotiations (Uesugi 2020: 2-3). Mid-space local bridge-builders or gatekeepers can "move across different cleavages in society to facilitate dialogue among competing stakeholders" (Uesugi and Kagawa 2020: 38). They are enabled by their unique social position to safeguard communities and channels of communication between them and other actors. Hence, they can become 'bridge-builders' who facilitate dialogue and peacebuilding or 'spoilers' who block passages of communication, undermining the peacebuilding process. While the book presents a conceptual basis for understanding the bridge- and dialogue-building roles of mid-space actors according to their specific settings, the architecture of the mid-space or the network of social and power relations within it is left under-examined. It also raises many questions about how this architecture shapes the opportunities and perspectives of mid-space actors, which can ultimately determine their motivations and actions. Although the concept of mid-space actors adds a constructive approach to substantiating the functions of hybridity as a lens, this chapter argues that it falls short of advancing hybridity from an analytical lens toward a peacebuilding tool.

The objective of this chapter is three-fold. First, it aims to critique the typology of mid-space local bridge-builders by combining various theoretical approaches pertinent to hybrid peacebuilding, specifically attempts to locate mid-space actors and their capacity to engage positively in conflict resolution. To overcome the barrier between theoretical and practical approaches, a combination of hybrid peacebuilding theory (including the knowledge outside intervenors have obtained from applying hybridity as an analytical lens) and the typology of mid-space local bridge-builders (including the meaningful engagement between outside intervention and local bridge-builders) is proposed in this chapter. Hence, this chapter explores how hybridity can be operated as a theoretical concept to analyse mid-space actors as well as being a practical tool to support them in their dialogue-building endeavours.

Secondly, the concept of bridge-builders is developed by locating midspace actors and their corresponding positionalities in the peace process. Several positionalities are identified in this chapter in terms of tapping into resources of formal and informal power, sharing a cultural background and thus means of social understanding within their community, and exercising skills toward transformative relationships, locally grounded 
legitimacy, and access to information. Relatedly, ways for outside intervenors and mediators to engage the bridge-building skills of mid-space actors, rather than reinforcing a hubristic approach to peacebuilding, will be explored. Such engagement is likely to promote the emancipatory potential of peacebuilding through genuine dialogue and active participation by local actors. Proposing this type of engagement rests on the assumption that bridge-building skills are inextricably tied to the actors involved and defined by their social relations and, hence, are not transferable to or easily manufactured by outside actors. Furthermore, these skills inform the mid-space actors' capacities to perform specific roles or functions within their society. This chapter, thus, interrogates whether these capacities can be enhanced by, and engaged with, broadening the possibilities for mid-space actors to positively shape peace negotiations.

Thirdly, this chapter attempts to advance the descriptive function of hybridity towards a more pragmatic approach to peacebuilding. Such an attempt entails propositions for several practical applications of the concept of hybrid peacebuilding that might be useful for outsiders when assisting with local conflict resolution. It is argued that this pragmatic approach has the potential to enable the agency of mid-space actors by relying on their context-specific knowledge on the one hand and proposing a way to engage with mid-space actors on the other hand. This chapter presents an outlook on how outside actors could engage meaningfully with mid-space actors.

Overall, this chapter explores the engagement of outsider intervenors with bridge-builders during a peace process. To do this the following discussion reviews the key concepts and definitions relevant to the conceptualisation and construction of a mid-space actor typology. Then, a critical analysis of this actor-based typology is presented, followed by identifying context-specific ways for outsiders to engage with mid-space actors by enabling their bridge-building capacity, without tarnishing local legitimacy and undermining access to crucial information. The chapter concludes by summarising the main arguments for advancing hybridity beyond an analytical lens and towards a practical tool for peacebuilding.

\section{Defining The Mid-SPACE}

This section scopes how scholars have previously defined the mid-space by examining connections and differences between these definitions. The investigation of the mid-space and the actors within it is not a novel 
approach to peace and conflict studies. Paul Wehr and John Paul Lederach (1991) earlier highlighted the potential of insider-partial mediators to connect conflicting parties effectively by using insider-specific knowledge obtained through their involvement as local actors. They used the term "middle-range" (similar to mid-space), where actors are able to cross between the top and bottom levels of society by creating a network of relationships and dialogue channels (Wehr and Lederach 1991: 8788). Actors who can use these channels (similarly to bridge-builders) are likely to expand their social web and connect various stakeholders. The mid-space thus holds the capacity to function as a transition zone, where information can be shared and relationships between different actors can be formed. On this basis Lederach (1997) later constructed a layered triangle model consisting of grassroots, middle, and elite sections in societies for understanding the interplay of actors in conflict resolution and post-conflict reconciliation processes. These ideas were advanced in the works of several academics (e.g., Newman and Richmond 2006; Mac Ginty 2010; Mac Ginty and Richmond 2013; Svensson and Lindgren 2013) articulating how inside-out mediation can facilitate dialogue among various stakeholders positioned in the top, middle, and bottom levels of society.

The concept of the mid-space encompasses the space in which the top, elite levels have the opportunity to interact with the bottom, grassroots or local level. Building on the work of Hancock and Mitchell (2018), Uesugi and Kagawa (2020) argue that the existing gap between toplevel focused peacemaking and ground-level based peacebuilding could be overcome by local bridge-builders through dialogue-building, using the mid-space as a "transit zone" (Mitchell 2018). This transit zone consists of various spheres of societies in which the top/national and bottom/local levels interplay via a "vertical gap" (signifying an intracommunity communication flow) and a "horizontal gap" (denoting inter-community communication) (Uesugi and Kagawa 2020: 38-39). In addition, the concept of the "diagonal gap" was introduced, which emerges in the space between the local community and international community, with the latter infiltrating the former by intervening in the conflict (ibid.: 38-40). It is not uncommon for these external, international interventions to ignore the local context, often creating debilitating circumstances or frictions in which local efforts are diminished over time (Millar 2014: 501-503; Uesugi and Kagawa 2020: 40-41). 
The idea of the mid-space stems from the critiques regarding liberal peacebuilding. It is suggested that liberal peacebuilding places too much emphasis on a top-down approach rooted in the ideas of institutionalism (Mac Ginty and Sanghera 2012: 3-8). Furthermore, it fails to recognise local agency and power structures as well as the social, political, and historical contexts in which peacebuilding takes place. Conversely, the grassroots-based approach takes a more 'local turn' and seeks to include more culturally sensitive and locally relevant methods of conflict resolution and peacebuilding (Mitchell 2018: 1-2). Hybridity, as a concept in peacebuilding, highlights the interplay between the local and the international and acknowledges hybrid peacebuilding outcomes (i.e., a combination of liberal and illiberal practices and outcomes) (Mac Ginty 2008). As defined in Chapter 1 and elaborated in Chapters 2 and 3, hybrid peacebuilding is considered in this study as an approach between liberal peacebuilding and the local turn, combining the 'best of both worlds' in terms of peace formation. As underlined in Chapter 2 the main selling point of hybrid peacebuilding is its ability to understand conflicts in their complexity. Applying the concept of complexity necessitates an examination of the historical and cultural background of a conflict, as well as the inclusion of all actors involved, while paying special attention to their power relations and interactions (Mac Ginty and Sanghera 2012: 3-8). As illustrated in Chapter 3, hybrid peacebuilding views the interaction of actors and institutions in a conflict-affected society as highly dynamic and diverse, calling for constant reconfiguration of peacebuilding processes.

Perhaps the most important question following the definition of the mid-space is about the actors who work in this space. As the most appealing aspect of the mid-space is that it provides an environment in which communication and information are shared, the question of who facilitates these occurrences is pertinent. The authors of Hybrid Peacebuilding in Asia argue for the existence of "mid-space actors" (Uesugi 2020: 2-3), who serve as intermediaries, being enabled by their unique social positions, resources, and transformative relationships to connect the various levels of peace formation. Consequently, they become the gatekeepers of their communities. Gatekeepers are often local leaders, or at times institutions, with high levels of local legitimacy while possessing the capacity to connect the top/national levels with the bottom/local levels, thus being able to travel among different adversaries (Uesugi and 
Kagawa 2020: 45). The classifications of these mid-space actors and their respective roles are critically examined in the following section.

\section{A Mid-Space Actor Typology}

Mid-space actors are individuals, institutions, or representatives of institutions involved in peacebuilding. They can be religious leaders, clan chiefs, security officers, or official representatives of organisations. Midspace actors can be classified according to their relational networks, as Chapter 3 demonstrates. Through their roles as gatekeepers (i.e., safeguarding communities and channels of communication between them and other actors) they can become either bridge-builders or spoilers. Gatekeepers are shaped based on their social history and background in connection to the underlying power relations that enable or block their bridge-building potential in peacebuilding processes.

Due to their unique positionalities in the mid-space, gatekeepers have the capacity to connect themselves with multiple communities and broker information and dialogue among them (Uesugi and Kagawa 2020: 50$51,54-55)$. Their positionalities allow them access to information and to obtain the needed legitimacy to engage with actors outside of their direct sphere of influence (Svensson and Lindgren 2013: 699-700). Gatekeepers can navigate in various directions, cross spheres and levels of interactions, and establish long-term relationships or bridges between stakeholders (Wehr and Lederach 1991: 85-98). Gatekeepers hold horizontal, vertical, and diagonal capacities that theoretically allow them to close gaps and establish dialogue platforms, if they are willing to do so-an aspect that will be discussed below (Uesugi and Kagawa 2020: 47-49). Gatekeepers can exercise various roles in conflict mediation based on their insider-partial perspective, which can be seen from different angles. For example, Chapter 3 examines their roles from a relationshipbased angle. Chapter 5 , on the other hand, discusses the identity of these actors based on their co-constitutive and contextual perspectives, which are influential in shaping the perceptions and attitudes of their respective local communities (Jackson and Albrecht 2018). These perspectives are dynamic, shaped by social interactions, and thus can be considered 'hybrid' in themselves.

Attitudes, behaviours, and situations are also crucial factors that could turn a gatekeeper to either a bridge-builder or a spoiler (Kagawa 2020: $10,14)$. In theory, both bridge-builders and spoilers incorporate the same 
abilities that put them in the position of a gatekeeper-a unique social position that enables them not only to engage with the local and the top/national but possibly also the international sphere. They also have vertical, horizontal, and diagonal capabilities (Uesugi and Kagawa 2020: 42 ) that allow them to cross existing gaps between conflicting spheres and communities, accessing information from several sources and establishing relationships. These capabilities refer to the ability to bridge over different blockages in a conflict-affected society, between national elites and the grassroots bottom (horizontal gap), among communities (vertical gaps), or the local and international contexts (diagonal gap).

Previous studies argue that actors who serve as gatekeepers have little motivation for sabotaging conflict resolution attempts because they are interested in the immediate outcomes of peace negotiations (Svensson and Lindgren 2013: 703). Hence, the chances of gatekeepers spoiling the peace process are low. However, spoiling is not necessarily against peace or in favour of conflict. For example, a gatekeeper may deem it beneficial for the peace process to block the flow of certain information and cut off pernicious relationships (Uesugi and Kagawa 2020: 44-48). Also, the goals of conflict parties during a negotiation process may differ according to their perceptions of what caused the conflict, and these perceptions are informed by their specific backgrounds and histories as well as their experiences of power hierarchies. These circumstances could lead gatekeepers to 'spoil' the peace process deliberately, not because it works against their own interest, but because they perceive 'spoiling' to be in the interest of their constituency. There is also a possibility of gatekeepers being side-lined during negotiations due to a lack of political agency and resources, resulting in their disengagement from the process (Jackson and Albrecht 2018: 43-44). These types of 'spoiling' might occur unintentionally or simultaneously while trying to bridge existing gaps. In the case of Cambodia, for example, Buddhist monks worked to bridge their communities and the international sphere. However, their attempts to challenge national policies through public demonstrations and other forms of nonviolent peace movements were suppressed easily by government forces. While they were able to bridge the communities they were engaged with their lack of advocacy towards the elites within the Buddhist community and national politicians undermined their capacity to connect the top/national and grassroots levels (Lee 2020). The link between 
conflict and the construction of identity, which could have imposed limitations on the Buddhist monks' ability to contribute to transformative relationships, will be elaborated in Chapter 5 .

The historical and contextual background of a conflict, the opportunities and limitations of existing power structures, and the parties' perceptions of themselves and others, as informed by their attitudes and behaviours, determine whether gatekeepers will act as spoilers (Kagawa 2020: 78). These factors are not necessarily negative or conflictpromoting; the perception of the outcomes of a negotiation process is, after all, subjective. However, understanding the interplay of these factors could bolster the potential for gatekeepers to turn into bridge-builders, especially when they are made aware of the costs and benefits of their actions for their constituency. In this context spoiling might be only a temporary measure, hence sometimes recurring, as the dynamics of a conflict or the perception of actors towards it shifts constantly. Spoiling should be seen as a fundamental part of the peace process when socioeconomic dynamics evolve and reorganise access to resources and information (Newman and Richmond 2006: 101-110). Therefore, spoiling does not necessarily jeopardise a peace process as a whole but instead changes the positions and angles of actors involved; peace then becomes an outcome of re-organising the structures and processes of negotiations.

The ambivalent position of a gatekeeper-whether perceived as a bridge-builder or spoiler, acting beneficially and/or disruptively towards a peace process-needs to be examined in the light of their social and power-relational backgrounds. What is perceived to be a 'spoiling' behaviour might not be aimed at tarnishing conflict resolution in the long-run but may simply be a means of readjusting and repositioning the actors involved (ibid.: 109). This is evident in the case of the Bangsamoro ceasefire agreements, in which rebel leaders go back and forth between engaging and disturbing negotiations whenever they do not feel adequately heard by the government. In instances when the peace process seems to reach a stalemate they re-engage by bringing in other actors, even potentially solidifying the peace process by broadening the spectrum of participants (Kagawa 2020: 71-72). Hence, analysing the processes of peace negotiations or peacebuilding entails caution to avoid binaries such as right versus wrong or bridge-building versus spoiling. These binary conceptualisations neither capture the complexity and dynamism of post-conflict societies nor differentiate between layers of behaviour, such as short-, mid- or long-term 'spoiling'. They also fail 
to consider the peace-promoting potential of spoiling and the conflictreinforcing potential of bridge-building from the viewpoint of other parties involved. It may thus be necessary to rethink the terms 'bridgebuilding' and 'spoiling' and assign them as equally vital capacities for gatekeepers-without judging them as 'good' or 'bad' for peacebuilding.

Determining the factors that enable the peace-promoting potential of a gatekeeper is of pivotal importance in this analysis. It is crucial to understand what pushes gatekeepers to use their unique positionalities and reach out to other actors across the horizontal, vertical, and diagonal gaps of peacebuilding. One relevant concept in this puzzle is that of "transformative relationships" (ibid.: 75-77). According to Kagawa (ibid.: 66-68), a transformative relationship is based on shared norms, values, and experiences that allow actors to connect to each other and express and act upon their interests to resolve a conflict. A gatekeeper can contribute to the cultivation of a transformative relationship by incorporating a relationship-oriented angle in order to rebuild trust and relationships with other actors from different conflicting groups. This angle entails looking not only at the actors and their capacities but also at how and to whom they are connected, and how frequently and in which ways these relations are utilised. Hence, it is important to consider what shapes a gatekeeper's perspective towards other parties, how relationships can enable and block engagement during peace negotiations, and how power hierarchies might encourage or hinder gatekeepers in developing such transformative relationships (Jackson and Albrecht 2018: 44-46). Those who foster these transformative relationships become bridge-builders while those who do not turn into spoilers.

The possibility of gatekeepers turning into either bridge-builders or spoilers (in some cases, gatekeepers exercise both roles simultaneously, see for example Lee 2020) demands a broader consideration of the gatekeepers' perspective on a conflict and perceptions of other conflicting parties, as well as the social characteristics that allow actors to take on the role of a gatekeeper (e.g., social status, horizontal, vertical, and diagonal capabilities, and capacity to foster transformative relationships) (Uesugi and Kagawa 2020: 56). Given these compounding characteristics of gatekeepers, the typology of mid-space actors can be a fruitful tool for identifying and analysing key peacebuilding actors and their positionalities in post-conflict settings. 


\section{Critique of the Typology}

While the typology of mid-space actors is broad enough to be applicable to a vast array of case studies, there are still some conceptual issues that need to be addressed. In particular, more specific definitions concerning the type of capacities of gatekeepers, how their backgrounds enable or restrict the development of those capacities, and how outsiders can engage with gatekeepers need to be substantiated. The following discussion dives into these issues in an attempt to bolster the conceptual soundness and nuance the categories embedded in the typology.

\section{Gatekeepers}

Firstly, the circumstances under which a gatekeeper becomes either a bridge-builder or a spoiler are not completely clear. Although Kagawa (2020: 75-76) introduced the idea of transformative relationships to fill this conceptual gap, the term itself remains underexplored. As mentioned earlier, Kagawa (ibid.: 66) defines transformative relationships as relationships "based on [gatekeepers"] common ground and social networks". She suggests that the "criteria for nurturing a transformative relationship include a healthy clan relationship, ethno-cultural-religious commonality, respective social ranks of the parties, and an authorised person to mobilise internal peacekeepers" (ibid.: 72). Social position is a key in becoming a gatekeeper, in particular the ability to exert "a strong influence over ordinary people" and "power to control the access of top leaders and outside intermediaries to the grassroots constituency under their realm of influence" (Uesugi and Kagawa 2020: 38). These positions can be summed up into two criteria: local legitimacy and access to information. Legitimacy is crucial for how gatekeepers connect the top/national and bottom/local levels. It determines whether actors on the ground are willing to adapt the normative narrative of peace according to how it is presented to them by their leaders. Peace, after all, has to be grounded or conveyed through a normative understanding that is rooted in the culture of a community (Lemay-Hébert and Kappler 2016). To transfer their aspirations and coalesce support, mid-space actors need to signify a culturally relevant peace narrative and garner trust from their constituents.

Local legitimacy enables gatekeepers to access information, forge relationships, and establish a base of support when other actors intend to spoil ongoing negotiations (Mitchell 2018: 3). For example, in 
Myanmar ethnic groups are highly fragmented and organised not only through representatives at the governmental level but also through selfadministered areas and arrangements on the township level (Jolliffe 2015). Within this structure actors with local legitimacy connect national government agencies or representatives and the local villages. They are not bound under the constitution and engage relatively freely and thus have the ability to advocate solely for their communities' interests. The lack of legal accountability raises the possibility of spoiling based on their perceived interests or subjective judgements rather than careful consideration of the needs of affected communities (ibid.: 32). For example, some ethnic group leaders in Myanmar have even encouraged violence against the government due to their lack of trust in the credibility of the latter. From a political power perspective, guaranteeing the involvement of grassroots communities influences heavily on the local legitimacy of local leaders, hence the absence of opportunities for local involvement would block the connection to the bottom spheres (Mitchell 2018: 3).

Legitimacy, according to Clements and Uesugi (2020), needs to be locally grounded, based on local culture and norms, rather than being imposed by an outside entity such as international organisations. This raises the question, however, of whether it would be possible to train mid-space actors as local bridge-builders to engage actively with the bottom/local during the peacebuilding process while outside intervenors remain in a more passive position. Would this kind of resolution process be more effective? Also, to what degree can local bridge-builders be guided by outside actors without being seen as yielding to the influence of the international community, which could jeopardise the consent of their constituent and damage their reputation? What is the role of the midspace as positioning factor for legitimacy and how is it shaped by political power? This chapter, as well as the subsequent empirical chapters, aims to clarify these questions.

\section{Political Power}

Locally grounded legitimacy can be understood as a hybrid form of legitimacy, combining traditional, charismatic, and rational legitimacy with normative and legal frameworks as it bridges a set of dichotomies such as traditional/modern, local/cosmopolitan, particularist/universalist (Uesugi 2018). It can be questioned, though, whether or not this legitimacy is able to bridge both sides. On one hand, the grassroots feel 
included, their values are protected, and their voices heard. On the other hand, a common ground is established where international and local frameworks can complement and enhance each other. How international and local arrangements for monitoring ceasefire agreements in Mindanao have enhanced each other to promote legitimacy through the inclusion of diverse actors who could supervise independently the enforcement of ceasefire agreements will be discussed in Chapter 6. This chapter, nevertheless, argues for the possibility of implementing international priorities for peaceful negotiations while providing a platform for the engagement of local actors.

In connection to the ability to tap into various forms of legitimacy, there is a need to substantiate how the architecture of the mid-space (i.e., the network of social and power relations) shapes the opportunities and perspectives for actors to emerge as gatekeepers. Furthermore, the characteristics required to overcome the blockage between different spheres inside a conflicting society remain under-examined. In this sense political power can be understood as an essential yet dynamic and evolving element that defines the space wherein gatekeepers operate. Thus, power itself can be seen as product of hybridity as it is shaped through the interaction of social actors behaving based on and in response to power relations that restrict and enable their actions. As Jackson and Albrecht (2018: $40)$ argue, the "power of local actors to resist the imposition of liberal statebuilding processes...shows that some hybrid structures do provide a means to subvert externally imposed statebuilding but, importantly, access to these approaches is controlled and moderated by the political power of local elites". Political power might then be one of the crucial factors that determines whether mid-space actors can develop and facilitate transformative relationships, obtain local legitimacy, and maintain access to information. It can be anticipated that power relations hinder dialogue, especially in conflict-affected societies (Newman and Richmond 2006: 107-108). Hence, it is fruitful to investigate how outside entities interact with existing power networks, clearing the blockages around the mid-space.

\section{Insider-Partial Mediators}

In addition to locally grounded legitimacy, the concept of transformative relationships can be substantiated by drawing on the definition of 'insider-partial mediators' presented by Svensson and Lindgren (2013). 
Insider-partial mediators are actors within a conflict-affected society who can take on mediation roles. They have the potential to "bring important indigenous resources to a peace process and $[\ldots]$ can complement external mediators by mitigating the bargaining problem of information failure", focusing specifically on their ability to negotiate out of their specific social position (Svensson and Lindgren 2013: 715). While their study explains how and why certain actors become bridge-builders, they do not include the possibility of those actors spoiling negotiation due to "issue bias" or an inability "to be strictly neutral to the issue at stake" (Svensson and Lindgren 2013: 703). This bias can also be caused by the actors' entanglement in a conflict, prompting them to evaluate the possible outcomes of their actions based on how those outcomes affect their homes and social reputations (ibid.: 699). Insider-partial mediators are ultimately shaped by their unique social position, granting them power and "pervasive institutional presence", resulting in "significant cultural power” (Appleby 2001).

What distinguishes insider-partial mediators from other parties involved in resolving a conflict (e.g., 'outsider neutral mediators' or actors who are not directly affected by the conflict and can thus be considered 'objective' mediators) is their unmatched access to intimate information about the other parties. These characteristics make insider-partial mediators an appropriate substitute or addition to outside intervention, which is almost always present in conflict resolution processes (Svensson and Lindgren 2013: 702-703). By building on trusting relationships among some or all conflicting parties, insider-partial mediators seek to create solutions explicitly relevant to their socio-economic and political environment, creating a more localised or contextualised rather than top-down, cookie-cutter approach. Embedded in the way actors access and share information at the core of the negotiation process highlights the importance of investigating what enables them to transfer information. It is crucial to see not only how information is transferred but also how frequently, and how this information generate impact on the strength of relationships between parties. Similarly, by observing how these information flow, it might possible to locate gatekeepers within a conflict situation. This flow of information can also be considered part of the dynamic nature and complexity of conflict affected societies as discussed in Chapter 3.

The question remains, however, of how outsider-neutral mediators (specifically, the international community) can engage effectively with 
insider-partial mediators. This chapter proposes a revision of the midspace actor typology by describing gatekeepers located in the mid-space who can become insider-partial mediators through bridge-building. It is also important to explore how the international community can assist gatekeepers in their access to information and knowledge and in enhancing their legitimacy. Most pressingly, is there a possibility for the international community, as the outsider-neutral mediator, to draw on transformative relationships, fostering and enhancing the engagement between the various stakeholders while guaranteeing an emancipatory approach? These possibilities, including the balancing of power hierarchies, could be the key elements in removing blockages around the mid-space and guaranteeing the development of dialogue. Such questions open the discussion on the following questions. Are these transformative relationships transferrable, since they are viewed as inherent to local actors in their specific setting? Do transformative relationships hold the potential for equal and mutual partnerships between insider-partial and outsider-neutral mediators? Can insider-partial mediators take full responsibility, enabling the international community as the outsider intervener or mediator to act in a capacity-building rather than a conflict resolution role? Under which circumstances within these configurations would the outsiders overstep their mandate and once again simply imprint liberal values of consensus-building and democratisation while overlooking local power dynamics?

In terms of outsider intervention and conflict resolution, the work of Mitchell and Banks (1996) can be used as basis for establishing a sensible and informed approach to negotiation. Coleman (2018) has created detailed descriptions of meaningful skills outsider interveners should encompass to contribute to ongoing peacebuilding endeavours.

In cases where the international community acts in a capacity-building role, and trains gatekeepers to use effectively their existing transformative relationships, the question of legitimacy is brought into the spotlight. Outsider interveners need to consider when and how to identify gatekeepers who are able and willing to receive capacity-building training. This kind of engagement can only be guaranteed through a deep and extensive understanding of the society one is engaging with. It also raises the issue of trust among outsider-neutral and insider-partial mediators, extended through them from their communities. Outsider-neutral mediators often have to deliver their mandate within a short timeframe and sometimes resort to engaging with elite actors with the technical capacity 
to act as gatekeepers but without legitimacy within their communities (von Billerbeck 2015).

There are various factors shaping the engagement of mid-space actors within a post-conflict society. How gatekeepers emerge in different forms and settings, including their social contexts, social identity, and formal and informal organisations that generate social order, will be discussed in Chapters 5 and 6. These factors return, once again, to the question of identifying and appropriately engaging with mid-space actors and whether a hybrid understanding of conflict and conflicting societies can help outsider-neutral mediators to approach gatekeepers. The following section will explore the potential application of the descriptive lens of mid-space actor typology in practice.

\section{From Descriptive to Practical?}

To bridge the gap between the descriptive lens and a practical approach to analytical frameworks for peacebuilding, such as the mid-space actor typology, it may be necessary to step back from an analytical perspective that tries to locate gatekeepers and their contribution to peace negotiations solely in terms of process. Instead, this chapter proposes an approach that helps the outside intervener to locate and engage with gatekeepers and contribute to their bridge-building in a meaningful manner. Such an approach needs to consider how to properly engage with gatekeepers and support their mediation role without jeopardising their local legitimacy. Peacebuilding scholars and practitioners have long recognised the importance of understanding the various factors influencing a community in a post-conflict environment in order to ensure appropriate local engagement. The 2015 review of the UN peacebuilding architecture states the following:

Numerous and varied stakeholders-public and private, domestic, regional and international-share the responsibility for peacebuilding. The multidimensional nature of sustaining peace is unavoidable and poses major challenges to achieving coherence; conflict and peace impact on every single person in a society. Reaching reconciliation and sustainable peace requires broad and inclusive participation, involving state and civil society stakeholders all the way down to the grass-roots level. (UNGA 2015) 
Building on this notion, Uesugi and Kagawa (2020: 48) claim that "it is possible to prevent the rise of spoilers and to convert them to constituents of the peace process, if we understand factors that influence the behaviour of a frustrated population". Given the dynamic nature of identities and societies, approaches to peacebuilding call for a constant re-configuration, re-negotiation and re-accumulation of knowledge regarding local communities. Peacebuilding further demands listening to evolving local perspectives on peace and what it takes to achieve it. Therefore, peace processes need to acknowledge the complexity of conflicts that require complex responses to the "highly dynamic, non-linear, and emergent" characteristics of societies (de Coning 2016). An adaptive typology that provides guidance on how to engage with gatekeepers while taking into account existing power structures embodies the complex nature of peacebuilding. Specifically, the capacity-building role of outside actors as mediators, as pointed out earlier, can contribute to the local resilience that is needed to cope with and adapt to change, including conflict.

There are several ways in which an outside intervener can influence the perspectives of gatekeepers on the peace process. First, outside interveners can train gatekeepers to acquire or enhance their skills to establish transformative relationships. As Kagawa (2020: 76-77) showcases in her analysis of the Bangsamoro peace process, ceasefire agreements served as initial diagonal platforms for opposed parties to engage through a formally established setting. This institutionalised form of engagement served as the base for the rebel and governmental parties to start negotiation and eventually sign a renewed peace agreement. It later informed more dependable, direct connections among the negotiating parties, proving to be a faster pathway for communication. As a result, the initial ceasefire agreements served as a learning experience for the opposing parties on how to approach, engage, and eventually establish transformative relationships between them.

Secondly, outside interveners can coordinate the transfer of knowledge among gatekeepers, connecting external and internal intermediation. Access to information conveyed through specific social positioning inside a community, as well as local legitimacy rooted in traditional sources, may be difficult to reproduce. However, the act of transmitting information and the type of information transmitted remains feasible. For example, actors with extensive knowledge of indigenous normative frameworks can, while conveying international norms to local people, merge the 
insider-partial perspective and outsider-neutral perspective (Honda 2018). This merging of perspectives directs transformative relationships toward opportunities for promoting mutual understanding.

Thirdly, outside interveners can assist in building the capacity of gatekeepers. The role a mid-space actor plays during a peace process depends on a combination of skills and resources acquired through formal training or social experiences. For example, UNDP, in cooperation with the Clingendael Institute (2019), organised capacity-building programmes for mediation experts to train young leaders of insurgent groups in Mindanao. The training enabled the participants to share and discuss their needs and perspectives with each other in a meaningful way, empowering them to actively support the peacebuilding process in southern Philippines while enabling their agency to engage with their respective communities (Lidasan 2016). These types of capacity-building programmes pave the way for accessing the local knowledge of inside actors while enhancing their mediation skills and situating the importance of those skills within the broader context of conflict resolution. With roles built upon their capacities, gatekeepers also form the basis for them to bridge gaps, build dialogue platforms, and sustain dialogue.

Finally, another approach to consider might be engaging with the power-relations present in a conflict-affected society that are shaping the mid-space. One can look at which dynamics within a conflicting society block free engagement between the grassroots bottom/local, mid-space, and top/national levels. It then can be questioned how gatekeepers might overcome these blockages with the assistance of outside intervention. Outsiders can provide the environment needed to connect, and they can train and strengthen gatekeepers' capacities necessary to promote dialogue among conflicting parties, bridging vertical, horizontal, and diagonal gaps. This might happen through granting access to information that creates an understanding of the conflict established not only within local settings, which are usually inaccessible to the international actors, but also from an outside, meso, or macro perspective. A further possibility is negotiation and leadership training that draws on already existing structures of legitimacy, in contrast to attempting to build a new and unfamiliar social hierarchy. This could entail, as seen in previous consensus-building approaches in Abidjan, Cote d'Ivoire by the Japan International Cooperation Agency, the establishment of local committee meetings in which local representatives chosen by their community members participated to discuss their collective needs (JICA 2016). 
This means gatekeepers are supported constantly in their role of developing relationships of trust with opposed parties-bridge-building or spoiling when necessary-and working towards sustained ties. At this point, some of the recommendations presented in this section remain on a theoretical level but will be discussed in the following empirical chapters and recapitulated in the concluding chapter.

\section{CONClusion}

Hybridity can be understood in different ways, being constantly shaped and re-shaped by the engagement of a myriad of actors and institutions (Mac Ginty and Sanghera 2012: 3-8). Hybrid peacebuilding seeks to understand peace and conflict as hybrid outcomes of a mixture of local and international norms situated within power structures and struggles. In hybrid peacebuilding, local communities can preserve their cultural values, norms, and practices while blending — not replacing-international (or universal) norms such as democratisation and the rule of law. It also encompasses a mixture of top-down and bottom-up approaches within the mid-space where both spheres meet and engage through a dynamic process of interactions involving all relevant actors.

How do we deal with this constantly shape-shifting concept in a way that allows us to operationalise the insights it generates? To contribute to answering this question, this chapter has unpacked the concept of the mid-space and applied a more fine-grained analysis of the peacebuilding agency of mid-space actors or gatekeepers who influence knowledge formation and norm expectation within their local communities. Through their social position, which grants them locally grounded legitimacy, access to information outside of their specific local context, and thus the ability to create transformative relationships, gatekeepers could emerge as agents of hybridity and-most importantly-hybrid peacebuilding. A typology that is attuned to the characteristics and skills of mid-space actors paves the way for a practical approach toward hybrid peacebuilding. As this chapter has demonstrated, this approach could include means of engaging and training gatekeepers from an outside perspective, empowering their peacebuilding endeavours, and enabling access to information that could shape their perception of a conflict. Through this approach, local leaders could emerge as active users of hybridity as a tool for accessing and sharing information and creating new understandings of local and international norms in an emancipatory way. 
To create a deep understanding of the various ways mid-space actors can get involved in peace processes and, subsequently, enhance the peacepromoting outcomes of their involvement, there has to be a more precise, yet comprehensive and adaptive, typology. This typology has the potential to encompass all relevant assets of gatekeepers without compromising their entrenchment in a highly complex environment. Hence, this chapter reconceptualises the typology of mid-space actors on the basis of the following considerations. First, mid-space actors are enabled through their unique social position to gatekeep their community from intruders. There are two aspects that shape this social position: access to different resources of power, both formal and informal, and a deep cultural and normative understanding of their community and regional context. Secondly, through this combination they encompass certain characteristics that are inherently tied to these actors and are thus difficult or impossible to reproduce for outside actors. These characteristics include their ability to forge transformative relationships, obtain locally grounded legitimacy, and gain access to information and resources. Thirdly, depending on their perception of a conflict, mid-space gatekeepers might evolve into either bridge-builders or spoilers. Bridge-builders are actors who actively engage in connecting themselves and their community to other actors on the top/national, bottom/local, and international levels. Spoilers are seen as doing the opposite by blocking passages and connections to others. However, spoiling does not inherently mean that actors are intentionally choosing to sabotage the peace process. As pointed out earlier, their act of 'spoiling' could be based on their assumption of what is valuable to them or their community at a given time or their view that the conditions of interaction need to be adjusted. Rather than perceiving spoiling as based on inherently ill intentions, it can be seen as point of intervention and re-configuring what is on the negotiation table (Newman and Richmond 2006: 109). This alternative view of spoilers demonstrates the need to revise the way peacebuilding actors are labelled and categorised.

A typology of mid-space actors according to their characteristics, resources, and forms of engagement with outsider interveners fills the gap between hybrid theory and peacebuilding practice. This typology not only describes mid-space actors, and their characteristics and skills, but also aims to keep the ever-evolving environment of social actors in mind and urges both scholars and practitioners to consider the complexity of conflict-affected societies. Based on this premise, taking the analytical lens of hybrid peacebuilding as a baseline for understanding insider-partial 
mediators as mid-space actors is proposed to provide an entry point for merging theoretical and practical approaches to hybrid peacebuilding.

\section{REFERENCES}

Appleby, R. S. (2001). Religion as an Agent of Conflict Transformation and Peacebuilding. In C. Crocker, F. O. Hampson, \& P. Aall (Eds.), Turbulent Peace: The Challenges of Managing International Conflict (pp. 821-840). Washington, DC: United States Institute of Peace Press.

Clements, K. P., \& Uesugi, Y. (2020). Conclusion. In Y. Uesugi (Ed.), Hybrid Peacebuilding in Asia (pp. 139-152). New York: Palgrave Macmillan.

Clingendael Institute. (2019). Insider Mediators Appointed in Bangsamoro Transitional Assembly. https://www.clingendael.org/news/insider-mediators-app ointed-bangsamoro-transitional-assembly\#.

Coleman, P. T. (2018). Conflict Intelligence and Systemic Wisdom: MetaCompetencies for Engaging Conflict in a Complex, Dynamic World. Negotiation Journal, 34, 7-35.

de Coning, C. (2016). From Peacebuilding to Sustaining Peace: Implications of Complexity for Resilience and Sustainability. Resilience, 4(3), 166-181.

Honda, M. (2018). Chapter 3 Coordination Challenges for the UN-initiated Peacebuilding Architecture: Problems in Locating 'Universal' Norms and Values on the Local. In M. Yamada \& M. Honda (Eds.), Complex Emergencies and Humanitarian Response (pp. 45-62). Osaka: Union Press.

Jackson, P., \& Albrecht, P. (2018). Power Politics and Hybridity. In J. Wallis, L. Kent, M. Forsyth, S. Dinnen, \& S. Bose (Eds.), Hybridity on the Ground in Peacebuilding and Development: Critical Conversations (pp. 37-49). Australia: Australian National University Press.

Japan International Cooperation Agency. (2016). The Project on the Reinforcement of Communities for Promoting Social Cobesion in Greater Abidjan (COSAY): Project Completion Report. Tokyo: Japan International Cooperation Agency (JICA).

Jolliffe, K. (2015). Ethnic Armed Conflict and Territorial Administration in Myanmar. The Asia Foundation. https://asiafoundation.org/resources/pdfs/ ConflictTerritorialAdministrationfullreportENG.pdf.

Kagawa, M. (2020). The Role of Rebel Gatekeepers in the Mid-Space in Peacebuilding: A Case Study of Bangsamoro. In Y. Uesugi (Ed.), Hybrid Peacebuilding in Asia (pp. 61-87). New York: Palgrave Macmillan.

Lederach, J. P. (1997). Building Peace: Sustainable Reconciliation in Divided Societies. Washington, DC: US Institute of Peace Press.

Lee, S. Y. (2020). Roles of Religious Leaders as Bridge-Builders: A Case Study in Cambodia. In Y. Uesugi (Ed.), Hybrid Peacebuilding in Asia (pp. 88-114). New York: Palgrave Macmillan. 
Lemay-Hébert, N., \& Kappler, S. (2016). What Attachment to Peace? Exploring the Normative and Material Dimensions of Local Ownership in Peacebuilding. Review of International Studies, 42(5), 895-914.

Lidasan, M. S. (2016). Negotiation and Mediation: Skills Needed for the Bangsamoro Peace Process. Sunstar.com. https://www.sunstar.com.ph/art icle/99439/Lifestyle/Lidasan-Negotiation-and-Mediation-Skills-needed-forthe-Bangsamoro-peace-process.

Mac Ginty, R. (2008). Indigenous Peace-Making Versus the Liberal Peace. Cooperation and Conflict, 43(2), 139-163.

Mac Ginty, R. (2010). Hybrid Peace: The Interaction Between Top-Down and Bottom-Up Peace. Security Dialogue, 41(4), 391-412.

Mac, G. R., \& Richmond, O. P. (2013). The Local Turn in Peace Building: a Critical Agenda for Peace. Third World Quarterly, 34(5), 763-783.

Mac, G. R., \& Sanghera, G. (2012). Hybridity Peacebuilding and Development: An Introduction. Journal of Peacebuilding \& Development, 7(2), 3-8.

Millar, G. (2014). Disaggregating Hybridity: Why Hybrid Institutions Do Not Produce Predictable Experiences of Peace. Journal of Peace Research, 51(4), 501-514.

Mitchell, C. (2018). By What Right? Competing Sources of Legitimacy in Intractable Conflicts. In L. E. Hancock \& C. Mitchell (Eds.), Local Peacebuilding and Legitimacy: Interactions Between National and Local Levels (pp. 1-19). Oxon: Routledge.

Mitchell, C., \& Banks, M. (1996). Handbook of Conflict Resolution: The Analytical Problem-Solving Approach. New York: Pinter.

Newman, E., \& Richmond, O. P. (2006). Peace Building and Spoilers. Conflict, Security \& Development, 6(1), 101-110.

Svensson, I., \& Lindgren, M. (2013). Peace from the Inside: Exploring the Role of the Insider-Partial Mediator. International Interactions, 39(5), 698-722.

Uesugi, Y. (2018). Chapter 4 Platforms for Dialogue and Hybrid Facilitators in the Bangsamoro Peace Process. In M. Yamada \& M. Honda (Eds.), Complex Emergencies and Humanitarian Response (pp. 65-86). Osaka: Union Press.

Uesugi, Y. (2020). Introduction. In Y. Uesugi (Ed.), Hybrid Peacebuilding in Asia (pp. 1-14). New York: Palgrave Macmillan.

Uesugi, Y., \& Kagawa, M. (2020). A Typology of Mid-Space Local BridgeBuilders. In Y. Uesugi (Ed.), Hybrid Peacebuilding in Asia (pp. 37-60). New York: Palgrave Macmillan.

United Nations, General Assembly. (2015). Letter dated 29 June 2015 from the Chair of the Secretary-General's Advisory Group of Experts on the 2015 Review of the United Nations Peacebuilding Architecture Addressed to the Presidents of the Security Council and of the General Assembly. New York: United Nations General Assembly. 
von Billerbeck, S. B. K. (2015). Local Ownership and UN Peacebuilding: Discourse Versus Operationalization. Global Governance: A Review of Multilateralism and International Organizations, 21(2), 299-331.

Wehr, P., \& Lederach, J. P. (1991). Mediating Conflict in Central America. Journal of Peace Research, 28(1), 85-98.

Open Access This chapter is licensed under the terms of the Creative Commons Attribution 4.0 International License (http://creativecommons.org/licenses/ by $/ 4.0 /)$, which permits use, sharing, adaptation, distribution and reproduction in any medium or format, as long as you give appropriate credit to the original author(s) and the source, provide a link to the Creative Commons license and indicate if changes were made.

The images or other third party material in this chapter are included in the chapter's Creative Commons license, unless indicated otherwise in a credit line to the material. If material is not included in the chapter's Creative Commons license and your intended use is not permitted by statutory regulation or exceeds the permitted use, you will need to obtain permission directly from the copyright holder.

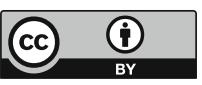

